\title{
Reading Abdul Fattah al-Sharif, Reading Elor Azaria: anti-Mizrahi racism in the moral economy of Zionist settler colonial violence
}

\section{Introduction}

On the morning of $24^{\text {th }}$ March 2016 in Hebron, Elor Azaria, a nineteen-year-old Israeli sergeant in the Kfir infantry brigade, raised his rifle and shot Abdel Fattah al-Sharif, a Palestinian, in the head. ${ }^{1}$ At the time Al-Sharif was lying wounded on the ground, surrounded by armed troops, having already been shot once after he stabbed and lightly injured an Israeli soldier. Another Palestinian assailant had also been shot dead. According to a leaked IDF report on the incident, prior to raising his rifle at al-Sharif, Azaria had told his company commander "he is a terrorist; he needs to die". ${ }^{2}$ Later that day, the human rights group B'Tselem released a video ${ }^{3}$ of the incident which went viral on Israeli social media and attracted international attention, sparking a huge political controversy. The IDF announced an investigation, calling the incident "very grave" and declaring that "this is not the IDF, these are not the values of the IDF and these are not the values of the Jewish people." ${ }^{4}$ Prime Minister Benjamin Netanyahu and Defence Minister Moshe Ya'alon both condemned the shooting. ${ }^{5}$ The military investigation swiftly led to an indictment and trial proceedings, the events of which were to dominate Israeli media and politics throughout 2016 and into 2017.

Politicians and members of the Israeli public quickly rushed to Azaria's defence. Although military censorship maintained his anonymity in official media, leaked information on the internet meant that his identity was widely known. ${ }^{6}$ Statements of support and criticisms of the military prosecution were issued by, among many others, Naftali Bennett (Education Minister from the national-religious "Jewish Home" party), Ayelet Shaked (Justice Minister from "Jewish Home") and Avigdor Lieberman (leader of the right-wing Yisrael Beitenu party). ${ }^{7}$ A large number of Israelis expressed support for Azaria on social media, with an online petition calling for him to be awarded a medal reaching tens of thousands

of signatures. ${ }^{8}$ Demonstrations and rallies in support of Azaria took place across Israel, most notably in Beit Shemesh, Ramla (Azaria's home town), and Tel Aviv. Polls of the Israeli public found that as many as 57\% did not support criminal charges against him. ${ }^{9}$ Following Azaria's indictment on $18^{\text {th }}$ April, the military gag order on his identity was finally lifted. In the face of the growing backlash, Netanyahu 
softened his earlier condemnation, calling for "balance" and "calm" and insisting that "our soldiers are not murderers". ${ }^{10}$ Public criticism of the IDF and Defence Minister Ya'alon, who still condemned the shooting, reached a new peak. Within a matter of weeks, in the context of coalition negotiations between the Likud and Yisrael Beitenu parties, Ya'alon resigned from the government in protest at being replaced by Avigdor Lieberman. ${ }^{11}$ The rift was widely interpreted in the context of the public row over the Hebron shooting. ${ }^{12}$

Over the several months of the trial, these debates continued to rage. The military prosecutor brought charges of manslaughter (notably not murder), whereas the defence held that Azaria had acted in selfdefence, fearing for his life. Azaria showed no remorse for his actions and continued to maintain his innocence. As the trial drew to a head, he received increasing public support. The right-wing magazine, Makor Rishon, named Azaria its "man of the year" at Rosh HaShana in 2016. ${ }^{13}$ And early in 2017 senior politicians, including Netanyahu, began to argue that Azaria should receive a pardon for any sentence. ${ }^{14}$ In January 2017, Azaria was at last found guilty - an extremely rare conviction for a serving soldier accused of killing a Palestinian - sparking fresh controversy and protests. However, Azaria then received a jail term of only 18 months for a crime which carries a sentence of up to 20 years, raising further criticism (as well as a backlash from those arguing that even this was too long) ${ }^{15}$ Lawyers estimated he could be released after as little as a year. In short, the Azaria shooting and trial constituted a major political event in Israel, electrifying public debate, splitting the cabinet and contributing to a ministerial resignation.

How should we explain this uproar? Clearly, the political fallout can be put in the context of growing splits in a divided right-wing government and a number of recent controversies in the relationship between the military establishment and right-wing politicians. ${ }^{16}$ Rules of engagement following stabbing attacks had also been a matter of intense public debate for several months prior to this episode in the context of the so-called "intifada of knives" in 2015. Yet this is not sufficient to explain why this incident in particular had sparked so much controversy. Such episodes are not at all uncommon in the occupied West Bank. During the stabbing attacks in late 2015, a large number of similar incidents were recorded. The human rights group B'Tselem had already reported in December 2015 that, in the 
previous two months, 71 assailants or suspected assailants had been shot dead by security forces. ${ }^{17}$ In many of these cases, the victims were also unarmed, wounded, or immobilised. Yet their deaths elicited little controversy among Israeli Jews. One common explanation, particularly on the Israeli Left, was that this incident was unique because it had been caught on camera, which forced the IDF into taking action it otherwise rarely views as necessary. Yet several similar incidents had also been clearly caught on camera, many of them also recorded and published by B'Tselem. ${ }^{18}$ They had not generated investigations, trials, public condemnation, or political backlash.

Another consideration presents itself: the identity of Azaria himself. Elor Azaria was a Mizrahi Jew from the poor neighbourhood of Ramla. His most vocal supporters (particularly those who attended demonstrations in Ramla and Beit Shemesh) came from a similar background, which is a social group which has formed a key part of the electoral base for the right-wing since 1977. Meanwhile, Azaria's most vocal critics tended to have a very different social profile, coming predominantly from the affluent Ashkenazi social, political, and military elite. Several Israeli commentators, initially online but eventually also in the mainstream Hebrew media, raised Azaria's Mizrahi background as a means of explaining the public furore. ${ }^{19}$ It was this feature of his persona which singled him out for prosecution and unprecedented public opprobrium, but which also helps explain the willingness of so many to come to his defence.

The reaction to Azaria's killing of al-Sharif therefore opens a series of questions about the nature of Israeli society. Undoubtedly it represents an important case study in the nature of the Ashkenazi/Mizrahi relations in Israel. Yet this intra-Jewish framing of the issue is insufficient to grasp the full dimensions of what this episode exposes. This episode prompts us to investigate the relationship between antiMizrahi racism and the moral legitimation of Israeli violence against Palestinians. In order to do this, in this essay I undertake a much deeper genealogy of the Azaria case, taking this contemporary example as a starting point for a wider historical and theoretical analysis. In particular, and in keeping with the theme of this special issue, I will argue that it is impossible to properly understand the significance of the relationship between anti-Mizrahi racism and the ethics of Israeli military violence without reference to the specificities of Zionist settler colonialism. I show that the particularities of Mizrahi 
racialisation, while resembling comparable processes of racialisation in other contexts, also reflect the precise realities of settler colonialism in Palestine. ${ }^{20}$ First, I show the way in which the wider Orientalism and racism of Zionist settler colonialism manifests itself in the stereotyping and vilification of Mizrahi Jews as especially violent and racist towards Palestinians. Second, however, I show how the particular racialisation of Mizrahim is shaped by a military sociology of inequality in which Mizrahim are disproportionally called upon to implement the most conspicuous forms of violence. Third, I then explore the ways in which Israeli military ethics racialises and communalises the (im)morality of settler colonial violence, stigmatising Mizrahim and elevating Ashkenazim as a means of masking and legitimating it.

\section{The figure of the violent Mizrahi as an Orientalist and racist stereotype}

Mizrahim have always had an ambiguous place in the Zionist settler colonial project. Zionism was originally envisaged primarily as a movement of European Jews for European Jews. It explained its ambitions explicitly as an attempt to bring European "civilisation" to the frontier of Asia, and it appealed for the support of European powers in these terms. ${ }^{21}$ Yet as the settlement of Palestine gathered pace, the Zionist movement came into increasing contact with Middle Eastern Jewish populations, both those living in Palestine and those in the wider region. These populations often spoke Arabic and were well integrated into their respective societies and cultures. Although they were given minority status and did face discrimination, many also led successful lives and were tolerated by the wider population. They generally had little interest in Zionist ideology, let alone the prospect of moving to Palestine. ${ }^{22}$ For the most part, the elite of the Labour Zionist movement was also circumspect about encouraging their immigration, for fear of importing what they saw as "Eastern" and Arabic ways of life as well as the poor "human material" they considered them to represent. ${ }^{23}$

However, this state of affairs began to change after the 1940s. The Nazi Holocaust, which eliminated vast swathes of the European Jewish population, and the closure of the Iron Curtain drastically reduced the prospect of further mass immigration from Europe. This prompted the Zionist movement to look more favourably on the Middle Eastern Jewish population as a potential pool of immigrants who could be drawn upon as a means of reversing the demographic balance in Palestine. As Yehouda Shenhav has 
documented, a joint oil refinery venture with the British Empire at Abadan was particularly significant in alerting the Zionist Organisation to the presence of Middle Eastern Jews and shaping its attitude towards them. ${ }^{24}$ Following the Nakba and the creation of the State of Israel, the Zionist movement worked closely with Arab governments to encourage Jewish populations to emigrate. Aided by the intensification of anti-Jewish violence in many of these countries at this time, their efforts were enormously successful, resulting in the transfer of hundreds of thousands of new immigrants (who often lost their property in the process, sometimes explicitly as part of deals between the Israel and these states). These Jews initially faced appalling conditions in transit camps (ma'abarot) and racism at the hands of state officials, before being permanently settled. ${ }^{25}$ Gradually, these diverse populations came to be collectively known as "Mizrahim" or "the Mizrahi sects". Discrimination, combined with poor education and living conditions in Mizrahi localities, has resulted in stark inequality between Ashkenazim and Mizrahim, to the extent that scholars have referred to these groups as distinct "ethnoclasses". ${ }^{26}$

It was the exigencies of the pure settlement project which prompted the Zionist movement to embrace Jewish immigration from the Middle East as a solution to its acute demographic challenges. Yet it was also the distinctively colonial and therefore Orientalist ideology of Zionism which shaped its attitude to the Mizrahim. In the view of many Zionists, the Mizrahim became suspect because of their association with the Arab world. Shenhav describes how, in the formative early encounter in Abadan, the local Iraqi Jews were described by Zionists in terms typical of the Orientalist discourses identified by Edward Said, as a backward people lacking in (European) culture. ${ }^{27}$ On the one hand, as Said argued, we can view these Orientalist discourses of Zionism as typical of colonial enterprises the world over. ${ }^{28}$ Yet they can also be seen as a specific inheritance, firstly, of the Zionist collaboration with British imperialism and, secondly, of the tendency within Zionist discourse to attempt to free European Jews of the stigma of European anti-Semitism by projecting these negative "Eastern" traits onto Mizrahim. ${ }^{29}$ Following Homi Bhabha, we might also understand the Zionist attitude to the Mizrahim as a form of racial stereotyping. Bhabha argues that the colonial encounter is always accompanied by anxiety and ambiguity regarding the difference between the coloniser and colonised. Since this difference is ultimately artificial and 
inconsistent, it must be fixed in place through the imagination of racial stereotypical traits in order to give coherence to the colonial worldview. ${ }^{30}$ The anxiety and ambiguity of the Zionist encounter with Mizrahim was particularly intense because of the paradoxical desire to both include them as Jews but exclude them as Arabs. Hence Zionism produced in response a plethora of stereotypes which persist to this day and which inform intra-Jewish racism in Israel.

Said noted the tendency of Orientalist discourse to portray Arabs as inherently violent. He traces this in part to the foundational significance of the Arab conquests for the European imaginary and the stabilisation of (white) European identity. ${ }^{31} \mathrm{He}$ also notes an ongoing Orientalist association between Arab culture and violence, one which today is manifested in the imaginary of the war on terror. ${ }^{32}$ This tendency clearly manifested itself in Zionist discourse concerning the Arabs, who "were seen as synonymous with everything degraded, fearsome, irrational, and brutal". ${ }^{33}$ Yet this stereotype of the Arab as violent also percolated into attitudes towards the Mizrahim, who were seen as tainted by their association with the Arab world. ${ }^{34}$ In her analysis of representations in popular Israeli cinema, for example, Ella Shohat highlights the tendency for Mizrahi characters to resort to violence, especially against Mizrahi women, who are often portrayed as oppressed or as victims of sexual violence. ${ }^{35}$

Many of these epithets found their way into representations of Elor Azaria and his supporters in the wake of the Hebron shooting controversy. Moshe Ya'alon, then Defence Minister, was among the most vocal public critics. Condemning the decision to hold a rally in Tel Aviv in support of Azaria, he stated: "It really worries me. Part of the power [of the IDF], as many have described it — [David] Ben-Gurion, Menachem Begin and others - is our ethical strength. We aren't Da'esh [ISIS]." ${ }^{36}$ The implicit comparison in these remarks between supporters of Azaria and ISIS appears to link their behaviour to a powerful Orientalist figuration of the "Arab terrorist". Sometimes the references to identity were even more explicit than this. Writing on his blog, the Israeli-American journalist Larry Derfner explicitly labelled the anti-Arab racism of Azaria's supporters as a predominantly Mizrahi "sickness": "The prevalence of fascist attitudes among undereducated Mizrahim, who are the majority in many poor and lower-middle-class urban neighbourhoods and development towns, means there is something very sick in that Israeli subculture". ${ }^{37}$ The language of some Ashkenazi Israelis on social media and newspaper 
comment sections also revealed the strength of these stereotypes. Responding to the common claim among supporters of Azaria that he should be thought of as "the child of us all", one commenter replied: “"A child of us all' my ass... go back to your transit camp [ma'abara] and let us fight the Arabs properly." ${ }^{" 38}$ And another commenter, using derogatory slang for a Mizrahi man, called Azaria "another ars who thinks he is above the law" ${ }^{39}$ Considering these comments, we should interpret the reaction towards Azaria not as sudden outpouring of concern for Palestinian welfare, but as righteous indignation with a long history in the anti-Mizrahi racism of Zionist settler colonialism.

This view of the Mizrahim should be intepreted not only as associated with Orientalism towards Arab culture, however, but also, as Haim Yacobi stresses, as linked with Israeli perceptions of Africa. ${ }^{40}$ This is not only true in relation to Mizrahim of direct North African origin, but also in the sense that the racialisation of Mizrahim can be situated in a wider, global construction of whiteness and blackness which takes representations of Africa and Africans as its crucial starting point. ${ }^{41}$ In this sense, the Zionist racialisation and stereotyping of Mizrahim might be understood as part of a broader phenomenon in which blackness is associated with violence and whiteness with peace and morality. ${ }^{42}$ Mizrahim have themselves often been keen to make comparisons between their own racialisation and that of African-Americans. This was famously evident in the creation of the Mizrahi Black Panther party in the 1970s in self-conscious imitation of its African-American predecessor. ${ }^{43}$ Shohat also points out "certain structural analogies between the oppression of Blacks in the New World and the situation of Sephardim in Israel. If the Palestinians can be seen as the aboriginal 'Indians' of the dominant discourse, the Sephardim constitute its 'Blacks.", ${ }^{44}$

However, useful though such insights are, reducing the stigmatisation of Mizrahim as violent to a product of Orientalism or anti-Blackness also risks eliding the specificities of Mizrahi racialisation in Zionist settler colonialism (as well as the specificities of anti-Black and anti-Palestinian racism). Crucially, whereas Palestinian Arabs and African-Americans have been strictly excluded from the dominant racial identity, Mizrahim have been permitted and encouraged to assimilate into the Jewish national collective, provided they repudiate their Arabness ${ }^{45}$ This has permitted their active participation in the settler colonial project, including in its violence. This participation extends beyond 
mere acquiescence. There is some evidence for an increased propensity among Mizrahim in certain localities to vote for Far Right parties which openly embrace strictly exclusionist and violent policies towards Palestinians. ${ }^{46}$ (Azaria himself appears to have been a supporter of Kahanist politics, as evinced through his membership of the virulently racist "La Familia" football supporters' groups.) These tendencies are easily exaggerated or over-generalised, and are often inadequately explained (by liberal Zionists in particular) in culturally essentialist terms with reference to Mizrahi backwardness, and to their non-European origins. ${ }^{47}$ Moreover, the continuities between these beliefs and wider Zionist ideology (supported by most Israeli Jews, Ashkenazi and Mizrahi alike) is often ignored. Indeed, such beliefs might more accurately be characterised as overt expressions of support for tendencies implicit within Zionism which others prefer to downplay. However, insofar as such political behaviour exists, it does have a clear sociological explanation. It derives from the marginalisation faced by the Mizrahi population, particularly by poorer communities in development towns, and from a desire to diminish this through inclusion in a nation defined in ethno-religious terms as Jewish. ${ }^{48}$

This political response can also manifest in a willingness to support violence against Palestinians. In research based on her interviews with low-ranking Mizrahi soldiers, Orna Sasson-Levy noted precisely this tendency and attributed it to a strategy of demonstrating ethno-national belonging and military prowess through violence against a figure of externalised Arabness. ${ }^{49}$ It is therefore insufficient to understand Mizrahi violence simply as a figment of racist or Orientalist stereotypes, even though the power of these stereotypes must be recognised (and their logic rejected). The racialisation of the Mizrahim must also be understood as part of a wider settler colonial logic which is designed both to secure Mizrahi participation in violence but also to attach a unique stigma to them for it. In order to develop a more nuanced understanding of this process, a closer examination of Israeli military sociology is required.

\section{Mizrahim in the Israeli military: the military sociology of inequality and coercion}

The Zionist project has continually required the exercise of enormous violence in order to enforce the gradual dispossession and subordination of Palestinians. ${ }^{50}$ This has manifested itself in the social importance of the military in Israeli society, most clearly exemplified in the conscription and reserves 
system. ${ }^{51}$ The Israeli military has often been held up as an example of a cultural "melting pot" which improves national integration and acts as a pathway of social mobility for peripheral social groups. ${ }^{52}$ However, more recent sociological analysis has fundamentally undermined this claim. Instead, the requirement of military service has been shown to deepen inequality in society and to produce a hierarchy of roles in which Mizrahim are expected to carry out the most conspicuous coercive functions. The Israeli sociologist Yagil Levy has identified the phenomenon of "materialist militarism" in Israel, whereby participation in the military has become a crucial means for the acquisition of social benefits (and hence the reproduction of inequality). ${ }^{53}$ Levy mentions the growth of the private sector and demographic change as key drivers of shifts in the way this military burden has been distributed and rewarded over time. However, we should also include reference to the changing patterns of settler colonialism, and the dynamics of Palestinian resistance to it, in order to understand these changes.

In the context of pre-existing racial and class hierarchies in Israeli society, the military has often served as a pathway for the further advancement of elites. Traditionally, the military was a bastion of the Labour Zionist establishment in which the officer corps, elite units, and combat roles were predominantly staffed by European Jews from central areas and kibbutzim. In exchange for their service, soldiers received a plethora of social benefits, including assistance with education, mortgages and social welfare, as well as social and cultural capital. Prior to the June war of 1967, this "republican equation" remained stable. However, following the military occupation of the West Bank and Gaza and the decline in the threat from the conventional armies of the Arab states (especially after the October war of 1973), important changes took place. The willingness of the Ashkenazi population to undertake military service declined in the face of the lower degree of perceived threats, the declining attractiveness of military work (especially the demands of occupying a civilian population), and the growing economic opportunities available to Israelis in the labour market (in part due to the economic benefits of the occupation to Israel). Rates of participation declined steadily, episodes of conscientious objection and refusal grew in number (especially during the Lebanon War and the First Intifada), and families became increasingly casualty averse. ${ }^{54}$ These trends became heightened as Palestinian military resistance assumed an irregular and/or civil character, in the form of the PLO-instigated armed struggle and in the 
outbreak of the First Intifada. Combating both of these required prolonged contact with civilian populations in which soldiering assumed the more taxing forms of police work and counterinsurgency. ${ }^{55}$

The problem of motivation became sufficiently acute that the military began to look to alternative recruitment models. It adopted a two-pronged approach: firstly, it incentivised military participation through competition in the labour market by providing greater financial rewards and skills training for some roles; secondly, it diversified the pool of manpower on which it drew, including an expanded role for Mizrahim (alongside the national-religious, Ethiopians, Russians, and others). ${ }^{56}$ However, this growing diversity did not reverse previous trends towards inequality, but entrenched them. Increasingly, Ashkenazi soldiers made a calculation about the likely social benefits of military participation and chose to serve either in high-status units (such as the pilots, special forces, or paratroopers) or in technical or cultural units where they could acquire transferable skills (such as military intelligence or army radio). ${ }^{57}$ These units were disproportionally open to them because of the educational and social pre-requisites for service, such as good high-school grades or experience in private preparatory courses. Meanwhile, Mizrahim participated either in low-status administrative roles or in the regular infantry, artillery, or armoured corps. ${ }^{58}$ The border police [mishmar hagvul], responsible for staffing checkpoints and policing some urban areas, became a particularly common destination for Mizrahi, Ethiopian, or Russian recruits.

The capacity of citizens to refuse or avoid military service, either selectively or in toto, has also been subject to racial stratification. In a society where the distribution of economic benefits and the sense of nation-belonging is tied to military service, a decision to decline this obligation (for whatever reason) is often very costly. These costs are most easily borne and mitigated by privileged social groups. Overt conscientious objection carries penal and social sanctions, which often requires access to legal or political support through personal networks. Meanwhile, "grey refusal" (where exemption is granted on medical or psychological grounds) requires a letter from a sympathetic doctor or psychologist. Those with access to societal resources, such as familial and community support or personal connections with medical or legal professionals, will certainly find this bargaining process easier - and wealthy 
Ashkenazim have been the main pioneers and beneficiaries of these methods ${ }^{59}$ As a result, the selective refusal of controversial or dangerous missions or roles remains more of an option for this social group.

This unequal and stratified distribution of coercive responsibility has had the result of increasing the visibility of Mizrahim in the perpetration of violence. This has been enhanced as the role of visual media in observing this violence grows. While vital in documenting abuses, human rights projects such as B'Tselem's “Shooting Back" programme, which donates cameras to Palestinian activists to help them record violations, tend to expose lower ranking soldiers to heightened scrutiny, further exposing them to criticism when these images circulate in the Israeli media. ${ }^{60}$ This military sociology of inequality and coercion was brought to light in a recent photographic exhibition called "Black Labour"61, which was created by the Israeli photographer Mati Milstein in collaboration with the Mizrahi activist Tom Mehager. ${ }^{62}$ The project brilliantly explores the moral economy of Zionist settler colonial violence. As Mehager concludes in a text to accompany the exhibition:

"Not only does Zionism necessitate a working class that will shoulder the burden of policing and maintaining order, it necessitates an underclass of moral inferiority. It necessitates a stable group that can be easily identified, and can be condemned and blamed for the ills of society. It is desirable to feel disgusted by a group of "brutish and uneducated Border Police officers," who are diametrically opposed to "the beautiful ones." This is how the disgusted can maintain his superiority." ${ }^{63}$

The title "Black Labour" very effectively draws out these logics of racialisation, showing how a "Black" underclass is produced through the labour of coercion. Viewed in this way, the violence of settler colonialism appears in no way extraneous to the hierarchy between Ashkenazim and Mizrahim: the two are inextricably linked. Yet the strength of this hierarchy and its imbrication in settler colonialism shape the pattern of Mizrahi racialisation - and resistance - in important ways. In understanding this point it is important to focus on the responses of Mizrahim themselves to these realities.

As noted above, it is significant that many Mizrahim are prepared to support the violence perpetrated by those such as Azaria. This was previously demonstrated in another recent controversy in the military, 
which also originated in Hebron: the case of "David the Nahlawi". In this episode, David Adamov, a soldier in the Nahal brigade, was filmed by Palestinian activists cocking his weapon towards a Palestinian youth during an argument, before kicking and verbally abusing him. Following Adamov's arrest (for a separate episode of violence towards his commander), thousands of Israelis, including many soldiers, took to social media to defend him by posting pictures of themselves holding signs which read "I am also with David the Nahlawi". The Mizrahi activist Itamar Taharlev noted that the bulk of support for Adamov came from "peripheral groups" in the army who occupy the lower ranks, whereas his critics tended to come from more privileged groups concerned with the external reputation of the military. ${ }^{64}$ Distinguishing between the "IDF of above" and the "IDF of below", the "strategic IDF" and the "border police IDF", Taherlev placed the controversy in a broader context using a sardonic colonial metaphor:

"In fact, the strategic IDF is the villa, whereas the border police IDF is the wall of the villa facing the jungle. And right now, when it looks from the villa as if the wall and the jungle are the same, its residents are going out to cut back the savages. Meanwhile, those who were promised that the IDF was the springboard to Israeliness discover that they have again become hewers of wood and drawers of water for the upstanding and glamorous hi-tech intelligence officers. ${ }^{95}$

Taharlev therefore also connects the creation of racial (and class) hierarchies with the constant need to delegate the colonial violence of the "villa" against the "jungle". However, he takes the analysis one step further by drawing our attention to the resentment and protests of Mizrahim themselves. This resentment was certainly expressed through criticism of the IDF top brass, but crucially this did not involve the repudiation of violence. Instead, as we observed with Sasson-Levy above, the response was quite the opposite: to identify even more strongly with the violence of the perpetrator as a means of claiming ethno-national belonging. This was no less apparent in the case of Elor Azaria, as the numerous demonstrations and petitions indicate. Indeed, this mode of expressing resistance appears to be highly effective. Not only was Azaria raised to the profile of a national hero by most of the public, including by senior Ashkenazi politicians, he also won the political backing of the Prime Minister (despite earlier criticism) and ultimately received an extremely light sentence. 
Again, the settler colonial context is crucial for understanding why this strategy of resistance is effective: Zionism will always reward participation in violence against Palestinians ahead of its repudiation. The real tragedy of the Mizrahi double-bind is therefore that it is only by seeming to confirm racist stereotypes, in a sense by playing along with the violent role assigned to them, that Mizrahim can best hope to improve their social standing. Nevertheless, even if participation in violence can help consolidate the Mizrahi position, this position still remains subordinate and Othered. Notable in this context was the disturbing spectacle of many Israeli parents dressing their children as Elor Azaria during the Jewish festival of Purim in 2016. ${ }^{66}$ This phenomenon displays all the signs of the ambivalence of colonial mimicry first analysed by Bhabha ${ }^{67}$ On the one hand it is strong evidence of the support for Azaria and of the widespread celebration, even furtive enjoyment, of his violence by many Israelis, Ashkenazi and Mizrahi alike. Yet on the other hand it underscores that the condition for this support is precisely that Azaria is imagined, celebrated, perhaps even Othered, as violent. Moreover, a certain reticence in identifying with Azaria is exposed in this practice, in that the identification with this stereotype can only be fully explored in the context of the Purim masquerade, a time when nothing is supposed to be quite what it seems. What explains this need to keep Mizrahi violence at a distance, even while it is embraced? As my next section explores, this is because the racialisation of Mizrahim also performs a vital move to settler innocence, and specifically Ashkenazi innocence, through the discourses of military ethics. ${ }^{68}$

\section{The racialization of military ethics in Israel}

While the violence perpetrated by Mizrahim is rendered hyper-visible through the inequalities of Israeli military sociology, Ashkenazi violence is correspondingly hidden. The actions of elite units dominated by Ashkenazim, such as fighter or helicopter pilots or special forces, can be just as violent as those of peripheral soldiers serving at checkpoints. Indeed, they are frequently more so. Yet the perpetrators in these incidents are by definition obscured from view. Moreover, this kind of violence is much more easily inserted into heroic narratives or legal and moral justificatory frameworks. Seen in this light, the open letter sent by the family of Elor Azaria to Moshe Ya'alon is highly revealing. They refer to Ya'alon's own past involvement in violence, including his role as head of the special forces unit (sayeret 
matkal) which killed the PLO commander Khalil al-Wazir (Abu Jihad) in an extra-judicial murder: "Do not forget that you were in the same position as our son when you were in Abu Jihad's room and made sure he was dead." ${ }^{69}$ Unlike in Azaria's case, however, this murder was an official secret for many years before its revelation earned Ya'alon further public plaudits for his military career.

Even in the particular case of the Hebron shooting a clear case can be made for the complicity and culpability of major Ashkenazi politicians. The Education Minister Naftali Bennet, the centrist MK Yair Lapid, and the former public security minister Yitzhak Ahronovitch all made public statements prior to the shooting in which they declared that all stabbing assailants should be shot dead, with implied legal protection for the soldier. ${ }^{70}$ Yet these elite figures escaped blame for this episode, which was instead directed towards Azaria, the poor Mizrahi soldier. By contrast, in similar cases involving Ashkenazi soldiers, such prosecutions and public outcries do not seem to take place. For example, Colonel Yisrael Shomer (commander of a brigade, and originally from a kibbutz) was cleared of all charges after he shot dead the 17-year-old Palestinian Muhammed Kasbeh in July $2015 .{ }^{71}$ Kasbeh had thrown a rock at Shomer's armoured jeep and was running away from the officer when he was shot in the back. After the shooting, Shomer and his fellow soldiers returned to their vehicle and drove away. The incident was partially captured on camera. Shomer offered exactly the same legal defence as Azaria did: that he felt in imminent danger and acted in self-defence. Yet the Military Advocate General ended its investigation before trial. $^{72}$

However, this tendency for Ashkenazi military violence to be obscured, downplayed, or denied, while clearly related to the military sociology discussed in the previous section, also has clear connections to another important phenomenon in Israeli society: the ideological role of military ethics in justifying settler colonial violence. The claim to be a moral army is of particular ideological significance to the Israeli military, which often proclaims itself "the most moral army in the world". While the record of the IDF in practice undermines this claim drastically, it remains the case that this belief serves as a powerful legitimating practice for the pursuit of military violence in Israel. Considerable effort is put into upholding the validity of this claim in the eyes of Israeli soldiers so that they continue to be motivated to fight. On closer inspection of some of these legitimating activities, it is possible to see that 
the image of Ashkenazi morality and non-violence is integral to the efficacy of this ideological operation. In other words, military ethics in Israel is thoroughly racialized.

A plethora of practices and discourses inside the Israeli military serve to reinforce the moral army myth, including the promulgation of an "ethical code", seminars and lectures for officers, training and workshops for serving soldiers, and preparatory classes for potential recruits at pre-military academies. As has been argued elsewhere, as well as providing moral justifications for the use of military violence, these activities also serve to turn soldiers into militarist ethical subjects - individuals whose selfunderstanding and self-perception is bound up with their ethical performance in war. ${ }^{73}$ In this way, military ethics can work to produce soldiers who are more motivated to fight and who seek selffulfilment in the pursuit of violent military activities. Yet it is also important to understand how this ethical process is implicated in the formation of wider militarist identities. In Israel, as elsewhere, militarism powerfully shapes gendered, racial, class, national, religious, and civic identities. ${ }^{74}$ Indeed, as it does so, it also reinforces hierarchies, in which a certain figure of Israeliness, usually white, Ashkenazi, and male, is privileged over others. ${ }^{75}$ The function of military ethics in the production of militarist identities is no different: the figure of the moral Israeli soldier with which soldiers are encouraged to identify is strongly associated with the qualities of the archetypal Israeli man of European origin. Moreover, this figure is also defined against its others, not least against the stereotypical figure of the Mizrahi, who as we have seen is stigmatised as violent and lacking in moral values. This can be seen directly in a number of aspects of military ethical pedagogy in the Israeli military, a few of which are explored below.

One of the main contexts in which issues of military ethics are taught in the IDF is the "Identity and Purpose" programme, which is delivered by the Education and Youth Corps in association with a number of private charities. In fact, it was Moshe Ya'alon who originally proposed these reforms during his tenure as Chief of Staff (2002-2005) in response to his concerns about declining levels of combat motivation. ${ }^{76}$ In the framing of this education programme, issues of religious pluralism are generally taught alongside matters of military ethics with the aim of promoting a common "Jewish" set of values. 
Describing his original rationale for the programme, the racial logic becomes increasingly apparent in Ya'alon's rhetoric:

"I was not always satisfied with the products of the Israeli school system that I encountered in the IDF $[\ldots]$ They were ignorant of the history of the Jewish People, of Jewish tradition. In the army, we teach the values of purity of arms and the sanctity of human life. Where do these values come from? When we speak about willingness to sacrifice one's life for the State of Israel, it is not an empty slogan; it rests on a profound basis. In the army, I found many examples of youth whom I can only describe as 'water sprouts'. Like water sprouts, these young people have no roots. They have no clue where they come from and have never engaged in clarifying their values. Some Israeli schools do not deal with values education at all. Some young people begin their army service without ever having been to Jerusalem. They are not familiar with the land for which they are supposed to sacrifice their lives, let alone acquainted with its history[...] I once had a driver from the south. He saw Tel-Aviv, Haifa, Jerusalem and the Galilee for the first time with me. He had never gone on his annual school trip because his family couldn't afford it. Until his army service, the furthest north he had ever been was to the home of relatives in Dimona. And he had no Jewish background to speak of - in his home they didn't bother with that. This is what I mean by 'water sprouts'."77

Ya'alon's botanical metaphor illustrates a barely concealed biological racism. The use of the term "water sprouts" to describe soldiers from remote and poor development towns in the South implicitly evokes comparison with the figure of the Sabra [tzabar], the native-born Israeli usually identified as Ashkenazi and named after another plant, the tough and hardy prickly-pear. In Ya'alon's imagination, what is needed is an educational programme which can "root" Mizrahim and other peripheral communities more firmly in the national collective, in ways which also resonate with the settler colonial attachment to territory. In this way, military ethics is part of an intra-Jewish version of the civilising mission, intended to bring the culture of Jerusalem and Tel Aviv to the backwards communities of the South (who are viewed as having no culture of their own). 
This attitude can also be found among those who are more directly involved in the teaching of military ethics. When I spoke with one teacher who ran ethics workshops as part of the Identity and Purpose programme for soldiers serving in the West Bank, she specifically noted that she found soldiers from the periphery the most problematic:

"It's a very anthropological, sociological situation. It's very interesting because most of the people in [the border police] are minorities, like you have Druze, you have very poor Mizrahim, Jewish people, and Ethiopians, and sometimes Russians, immigrants. It's interesting to see that they are the most abusive, most hateful. Like the hate or the political incorrectness is most in your face there. Like, in your face."78

This creation of a simultaneously moral and racial hierarchy through military ethics teaching can also be detected in the work of the pre-military academies (mekhinot kdam tzva'iyot). These academies are informal educational institutions attended by high-school graduates who postpone their army service for one year as part of the training programme. Originally, the academy programme was restricted to religious soldiers and to secular students from elite backgrounds. More recently, however, the army has become interested in the capacity of academies to increase enlistment from peripheral communities. Accordingly, there are a number of both secular and religious academies which aim to attract these students. ${ }^{79}$ Military ethics and Jewish education are a core part of the curriculum at pre-military academies, with the aim of instilling appropriate values among new recruits and making them more inclined to serve in the military. Again, when this pedagogical approach is applied to students from peripheral communities it acquires the character of a civilising mission. As one teacher at a pre-military academy told me,

"Here in this mekhina we try very hard to bring people from all kinds of places [...] They come from all different places in Israel, like the centre - the kibbutzim and the main cities - but also from the periphery, like Beer Sheva, and Kiryat Gat, and Kiryat Shmona. And in those places most of them are $[\ldots]$ they come with many less humanist thoughts and even sometimes racist opinions. So it's very difficult because we can do a lesson [about military ethics] and they will 
say mavet la'aravim ["death to the Arabs"] or "they are shooting me, so shouldn't I take revenge?" 80

Claims about the morality or immorality of military violence in Israel are therefore deeply implicated in the production of racial hierarchies. Military ethical discourses depend on being able to establish a distinction between "good" and "bad" soldiers, and therefore often draw on and deepen existing racial hierarchies in order to consolidate this image. However, also common to all these efforts is a belief in the possibility of integrating or "rooting" Mizrahim within the ethno-national collective through an educational civilising mission. There is an implied permeability to the bounds of the ethnonational community, even as this moral and racial hierarchy is deepened and elaborated.

This particularity of Mizrahi racialisation in Israeli military ethics offers evidence of its specific function in Zionist settler colonialism. This relates not simply to the demographic imperative to include as many Jews as possible within the nation: it also relates to the ideological requirements of legitimating settler colonial violence. As Patrick Wolfe famously noted, the violence of settler colonialism is part of a fundamental "logic of elimination" in which invasion is "a structure, not an event". ${ }^{11}$ Without a fundamental process of decolonisation, this violence is immutable. It does not yield to the moral improvement of those who are tasked with implementing it. Indeed, in a situation of military occupation, episodes of murderous violence such as those explored in this essay are inevitable. Beyond these notable outbursts of killing, the deeper structural violence of occupation and colonialism also remains. A checkpoint is itself violent, regardless of the morality of the soldier who stands by it. Moreover, as a structure, the violence of settler colonialism emanates from all those who participate in its social fabric, not only those charged with policing it in the most visible ways. Naturally, Israeli military ethics does not address itself to these issues because they raise fundamental and troubling questions about the nature of occupation and indeed of Zionism. Instead, it focusses on notions of personal values and individual character in soldiers because they offer the illusion that an enlightened occupation is possible, if only soldiers could be made more moral. Frequently, this serves to depoliticise, moralise, and individualise questions of violence, making it seem as though violence arises from the actions of "bad apples" rather than an underlying political structure. Yet, as I have shown, this strategy of legitimation can also operate 
by "communalising" this blame, attaching it not just to corrupted individuals but also to racialised groups. By blaming the violence of settler colonialism on Mizrahim, the Ashkenazi elite not only exculpates and exalts itself: it also transforms this violence from a political into a moral question, from a structure into an event. This makes the stigmatisation of the Mizrahim an integral ideological operation of the Zionist settler colonial project.

\section{Conclusion: readings and counterreadings}

In her incisive study of the beating of Rodney King by four Los Angeles police officers in 1991, Judith Butler asks how it was possible for the jurors in the subsequent trial to acquit the officers despite having been shown a twelve-minute-long video of the policemen hitting King repeatedly as he lay helpless on the floor. What made this case all the more shocking was that the video was presented to the jury by the defence attorney as evidence of their innocence:

"How could this video be used as evidence that the body being beaten was itself the source of danger, the threat of violence, and, further, that the beaten body of Rodney King bore an intention to injure, and to injure precisely those police who were either wielding the baton against him or stood encircling him?"82

Butler's answer is that the jurors viewed the video through the racist episteme of whiteness, in which "the black male body, prior to any video, is the site and source of danger". ${ }^{83}$ This makes it impossible for the actions of the police to be read as violent:

"The police are $[\ldots]$ structurally placed to protect whiteness against violence, where violence is the imminent action of that black male body. And because within this imaginary schema, the police protect whiteness, their own violence cannot be read as violence..."84

Instead, the "intention" to harm is transposed to King by virtue of his racialization as Black. In opposition to this racist reading of the video of King's beating, Butler offers "an aggressive counterreading" of the video: 
"it is necessary to read not only for the "event" of violence, but for the racist schema that orchestrates and interprets the event, which splits the violent intention off from the body who wields it and attributes it to the body who receives it." ${ }^{" 85}$

In this article, I have been engaged in a similar counterreading of the video of the murder of Abdul Fattah al-Sharif at the hands of Elor Azaria. Rather than limiting my focus to the "event" of the murder, I have also sought to read through its interpretation in Israeli society the structure of the racist schema of Zionist settler colonialism. However, what I have found is that there are in fact two superimposed readings of this event in Israeli society, both of which can be counter-read to reveal different features of this racist moral economy of violence. At the level of simple analogy, the parallels between the beating of Rodney King and the shooting of Abdul Fattah al-Sharif are clear. The defenders of Azaria, just like the jurors in the trial of the police officers, cannot see the violence Azaria wields in the video. Rather, the violence they see comes from the immobilised and wounded body of al-Sharif, whose racialization as an "Arab terrorist" turns him into a source of danger and sanctions murder against him. This is the racist schema of settler colonialism at its most obvious. Yet there is a second racist reading of the episode, the one enacted by Azaria's Zionist critics. When they view this video, they also do not see the structural and racist violence of settler colonialism. They do not see the wider complicity of the Zionist project in this episode. More specifically, they do not see any Ashkenazi violence in this video: they only see Mizrahi violence. The violence they see is located in Azaria's intentions, not as an agent of the settler colonial project, but as a Mizrahi who should have known better. No one and nothing else is culpable.

Against both of these racist readings of the shooting, I have argued that the reactions to this episode cannot be separated from the wider role of racism in the moral economy of Zionist settler colonial violence. Of course, this episode vividly confirms the expendability of Palestinian lives in the enforcement of colonial order in the West Bank. Yet it also reveals the strategies through which the deep structure of this violence is maintained through the racialisation of Mizrahim. As I have shown, this racialisation is not reducible to wider racist and Orientalist discourses, even though these do offer important discursive resources. Rather, it is also shaped by the requirements of a military sociology of 
inequality in which Mizrahim are disproportionately called upon to mete out the most conspicuous forms of settler colonial violence. This sociology also defines the precise contours of this racialisation, given the necessity of continued Mizrahi participation in that violence. A closer examination of Israeli military ethics illustrated these contours. Instead of presenting Mizrahim as irredeemable, these discourses regard Mizrahim as both morally inferior but also amenable to moral improvement through a civilising mission. This particular form of racialisation allows for the structural nature of settler colonial violence to be concealed: on the one hand it is excused as the product of Mizrahi backwardness; on the other it is presented as redeemable through moral and racial progress. Viewed from this perspective, anti-Mizrahi racism emerges not as an ephemeral, contingent, or disappearing feature of Zionist settler colonialism, but as a central and structural part of it.

\footnotetext{
${ }^{1}$ Peter Beaumont, "Israeli Soldier Is Filmed Shooting Dead Wounded Palestinian Attacker," The Guardian, March 24, 2016, https://www.theguardian.com/world/2016/mar/24/israeli-soldier-filmed-shoot-dead-woundedpalestinian-attacker-hebron; Elior Levy, Yoav Zitun, and Elisha Ben Kimon, "IDF Soldier Shoots Neutralised Terrorist in the Head," Ynet News, March 24, 2016, http://www.ynetnews.com/articles/0,7340,L4782563,00.html.

${ }^{2}$ Ben Bryant, "Leaked IDF Report States Soldier Who Shot Palestinian Attacker Driven by 'Twisted Ideology," Vice News, April 28, 2016, https://news.vice.com/article/exclusive-leaked-idf-report-states-soldierwho-shot-palestinian-attacker-driven-by-twisted-ideology-1.

${ }^{3}$ B'Tselem, "Soldier Executes Palestinian Lying Injured on Ground after the Latter Stabbed a Soldier in Hebron," March 24, 2016, http://www.btselem.org/firearms/20160324_soldier_executes_palestinians_attaker_in_hebron. ${ }^{4}$ Itamar Sharon, "Netanyahu, Ya'alon Slam Hebron Shooting as IDF Vows Probe," Times of Israel, March 24, 2016, http://www.timesofisrael.com/idf-vows-probe-into-hebron-shooting-these-arent-jewish-values/. ${ }^{5}$ Ibid.

${ }^{6}$ Richard Silverstein, "IDF Soldier Who Executed Unarmed Palestinian, and His Battalion Commander Exposed," Tikun Olam, March 24, 2016, http://www.richardsilverstein.com/2016/03/26/breaking-identities-ofidf-soldier-who-executed-unarmed-palestinian-and-his-commanding-officer-exposed/.

${ }^{7}$ Gil Stern, "Soldier Held for Hebron Shooting to Be Questioned amid Major Political Uproar," Jerusalem Post, March 29, 2016, http://www.jpost.com/Arab-Israeli-Conflict/Soldier-held-for-Hebron-shooting-to-bequestioned-amid-major-political-uproar-449510; Moran Azoulay, "Bennett Clashes with Netanyahu over Hebron Incident," Ynet News, March 27, 2016, http://www.ynetnews.com/articles/0,7340,L-4783611,00.html. ${ }^{8}$ Ali Abunimah, "Israelis Rally around Soldier Filmed Executing Injured Palestinian," Electronic Intifada, March 28, 2016, https://electronicintifada.net/blogs/ali-abunimah/israelis-rally-around-soldier-filmed-executinginjured-palestinian.

${ }^{9}$ Robert Mackey, "Most Israelis Say Army Medic Who Killed Wounded Suspect Is Not a Murderer," The Intercept, March 28, 2016, https://theintercept.com/2016/03/28/israelis-reject-murder-charge-army-medickilled-wounded-suspect/.

${ }^{10}$ Tamar Pileggi, "Netanyahu Urges 'Balance' in Trial for Hebron Shooter," Times of Israel, April 19, 2016, http://www.timesofisrael.com/netanyahu-urges-leniency-for-in-trial-for-hebron-shooter/.

${ }^{11}$ James Glanz and Irit Pazner Garshowitz, "Moshe Yaalon, Israeli Defence Minister, Resigns," New York Times, May 20, 2016, http://www.nytimes.com/2016/05/21/world/middleeast/moshe-yaalon-israeli-defenseminister-resigns.html.

${ }^{12}$ Ibid.
} 
${ }^{13}$ Yael Marom, "The Camera That Made Elor Azaria 'Man of the Year,"” +972 Magazine, October 2, 2016, https://972mag.com/the-camera-that-made-elor-azaria-man-of-the-year/122371/.

${ }^{14}$ Peter Beaumont, "Netanyahu Backs Call for Convicted Israeli Soldiers to Be Pardoned," The Guardian, January 4, 2017.

${ }^{15}$ Bethan McKernan, "Elor Azaria: Israeli Soldiers Sentenced to 18 Months in Jail for Shooting Dead Wounded Palestinian Attacker," The Independent, February 21, 2017.

${ }^{16}$ Amos Harel, "Has the Israeli People's Army Lost the People?," Ha'aretz, May 11, 2016, http://www.haaretz.com/israel-news/.premium-1.719056.

${ }^{17}$ B'Tselem, "Unjustified Use of Lethal Force and Execution of Palestinians Who Stabbed or Were Suspected of Attempted Stabbings," December 16, 2015,

http://www.btselem.org/gunfire/20151216_cases_of_unjustified_gunfire_and_executions.

${ }^{18}$ Ibid.

${ }^{19}$ Adi Mazor and Tom Mehager, "What Would We Say about the Hebron Shooter Were He Ashkenazi?," +972

Magazine, March 31, 2016, http://972mag.com/what-would-we-say-about-the-hebron-shooter-were-he-

asheknazi/118278/; Eness Elias, "Is Elor Azaria (also) being punished because he is Mizrahi?," Ha'aretz, July 21, 2016; Uri Avnery, "When and How the Ashkenazi-Mizrahi Rift Was Born," Haaretz, February 28, 2017, http://www.haaretz.com/opinion/.premium-1.774087.

${ }^{20}$ In this, I broadly follow the approach of Patrick Wolfe. See his Traces of History: Elementary Structures of

Race (London: Verso, 2016).

${ }^{21}$ Edward Said, "Zionism from the Standpoint of Its Victims," Social Text 1 (1979): 31-37; Yoav Peled and Gershon Shafir, eds., Being Israeli: The Dynamics of Multiple Citizenship (Cambridge: Cambridge University Press, 2002), 75.

${ }^{22}$ Ella Shohat, "Sephardim in Israel: Zionism from the Standpoint of Its Jewish Victims," Social Text 19/20 (1988): 9-11.

${ }^{23}$ Peled and Shafir, Being Israeli: The Dynamics of Multiple Citizenship, 74-75, 77-78; Tom Segev, 1949: The First Israelis (New York: Henry Holt, 1998), 155; Joseph Massad, The Persistence of the Palestinian Question (London: Routledge, 2006), 57-61.

${ }^{24}$ Yehouda Shenhav, The Arab Jews: A Postcolonial Reading of Nationalism, Religion, and Ethnicity (Stanford: Stanford Univeristy Press, 2006), 19-76.

${ }^{25}$ Segev, 1949: The First Israelis, 155-194; Shohat, "Sephardim in Israel: Zionism from the Standpoint of Its Jewish Victims," 16-20; Massad, The Persistence of the Palestinian Question, 62-63.

${ }^{26}$ Oren Yiftachel, Ethnocracy: Land and Identity Politics in Israel (Penn Press, 2006), 203.

${ }^{27}$ Shenhav, The Arab Jews: A Postcolonial Reading of Nationalism, Religion, and Ethnicity, 70-76.

${ }^{28}$ Said, "Zionism from the Standpoint of Its Victims," 25-29; Edward Said, Orientalism (London: Penguin, 2003).

${ }^{29}$ Aziza Khazoom, "The Great Chain of Orientalism: Jewish Identity, Stigma Management, and Ethnic

Exclusion in Israel," American Sociological Reviews 68, no. 4 (2003): 481-510.

${ }^{30}$ Homi Bhabha, The Location of Culture (Oxford: Routledge, 2004), 94-120.

${ }^{31}$ Said, Orientalism, 59-60.

${ }^{32}$ Ibid., 286-287; Derek Gregory, The Colonial Present: Afghanistan, Palestine, Iraq (Oxford: Blackwell, 2004).

${ }^{33}$ Said, "Zionism from the Standpoint of Its Victims," 33.

${ }^{34}$ Henriette Dahan-Kalev, "Zionism, Post-Zionism, and Fear of Arabness," in Fear Itself: Reasoning the Unreasonable, ed. Stephen Hessel and Michele Huppert (New York: Rodopi, 2005), 163-74.

${ }^{35}$ Ella Shohat, Israeli Cinema: East/West and the Politics of Representation, second edition (London: IB Tauris, 2010), 112, 140-150.

${ }^{36}$ Jack Moore, "Israeli Defence Minister: Rally for Convicted IDF Shooter Is Akin to Supporting ISIS," Newsweek, April 19, 2016, http://europe.newsweek.com/israeli-defense-minister-rallying-convicted-idf-shootersupporting-isis-449622?rm=eu.

${ }^{37}$ Larry Derfner, "Who Are in the Mobs behind Israeli Army Sgt. Elor Azaria?," April 23, 2016,

http://www.larryderfner.com/2016/05/07/who-are-in-the-mobs-behind-israeli-army-sgt-elor-azaria/.

${ }^{38}$ Elias, "Is Elor Azaria (also) being punished because he is Mizrahi?".

${ }^{39}$ Ibid.

${ }^{40}$ Haim Yacobi, Israel and Africa: A Genealogy of Moral Geography (Oxford: Routledge, 2016), 77-90.

${ }^{41}$ Shohat, Israeli Cinema: East/West and the Politics of Representation, 106-107; on the construction of European Jews as "honorary whites" through the Zionist colonial project see Massad, The Persistence of the Palestinian Question, 82-88. One can obviously extend this observation to the racialisation of Ethiopian Jews.

${ }^{42}$ Frantz Fanon, Black Skin, White Masks (London: Pluto Press, 1986), esp. 138-150; Judith Butler,

"Endangered/endangering: Schematic Racism and White Paranoia," in Reading Rodney King/Reading Urban Uprising, ed. Robert Gooding-Williams (London: Routledge, 1993), 15-22. 
${ }^{43}$ Sami Shalom Chetrit, Intra-Jewish Conflict in Israel: White Jews, Black Jews (Oxford: Routledge, 2010), 81140.

${ }^{44}$ Shohat, Israeli Cinema: East/West and the Politics of Representation, 107.

${ }^{45}$ Wolfe, Traces of History: Elementary Structures of Race, 61-83, 256-270; See also Noura Erakat,

"Whiteness as Property in Israel: Revival, Rehabilitation, and Removal," Harvard Journal on Racial and Ethnic Justice 31 (2015): 78-83.

${ }^{46}$ Yoav Peled, "Ethnic Exclusion in the Periphery: The Case of Oriental Jews in Israel's Development Towns,"

Ethnic and Racial Studies 13, no. 3 (1990): 345-67.

${ }^{47}$ Shohat, "Sephardim in Israel: Zionism from the Standpoint of Its Jewish Victims," 3, $26-29$.

${ }^{48}$ Yiftachel, Ethnocracy: Land and Identity Politics in Israel, 227-235; Peled, "Ethnic Exclusion in the

Periphery: The Case of Oriental Jews in Israel's Development Towns."

${ }^{49}$ Orna Sasson-Levy, "Military, Masculinity, and Citizenship: Tensions and Contradictions in the Experience of Blue-Collar Soldiers," Identities: Global Studies in Culture and Power 10, no. 3 (2002): 336-339.

${ }^{50}$ Zachary Lockman, "Land, Labour and the Logic of Zionism: A Critical Engagement with Gershon Shafir," Settler Colonial Studies 2, no. 1 (2012): 9-38. It is important to note that this violence is not exclusively military. However, I concentrate on the military here as an exemplification of wider trends and because of its relevance to the Azaria case.

${ }^{51}$ See, inter alia, Baruch Kimmerling, "Patterns of Militarism in Israel," European Journal of Sociology 34, no. 2 (1993); David Maman, Eyal Ben-Ari, and Ze'ev Rosenhek, eds., Military, State and Society in Israel:

Theoretical and Comparative Perspectives (New Brunswick: Transaction Publishers, 2001); Eyal Ben-Ari and Edna Lomsky-Feder, eds., The Military and Militarism in Israeli Society (Albany: State University of New York Press, 1999); Oren Barak and Gabriel Sheffer, eds., Militarism and Israeli Society (Bloomington: Indiana University Press, 2010).

${ }^{52}$ Uri Ben-Eliezer, "A Nation-in-Arms: State, Nation, and Militarism in Israel's First Years," Comparative Studies in Society and History 37, no. 2 (1995): 264-85.

${ }_{53}^{5}$ Yagil Levy, Israel's Materialist Militarism (Lanham: Lexington Books, 2007); Yagil Levy, "Militarizing Inequality: A Conceptual Framework," Armed Forces and Society 27, no. 6 (1998).

${ }^{54}$ Levy, Israel's Materialist Militarism, 128-145; Yagil Levy, Israel's Death Hierarchy: Casualty Aversion in a Militarised Democracy (New York: NYU Press, 2012), 71-108; Sara Helman, "Citizenship Regime, Identity and Peace Process in Israel," in Military, State and Society in Israel: Theoretical and Comparative Perspectives, ed. David Maman, Eyal Ben-Ari, and Ze'ev Rosenhek (New Brunswick: Transaction Publishers, 2001).

${ }^{55}$ Eyal Ben-Ari, "Masks and Soldiering: The Israeli Army and the Palestinian Uprising," in The Military and Militarism in Israeli Society, ed. Eyal Ben-Ari and Edna Lomsky-Feder (Albany: State University of New York Press, 1999); Erella Grassiani, Solidering Under Occupation: Processes of Numbing Among Israel Soldiers in the Al-Aqsa Intifada (Oxford: Berghahn Books, 2013); Sergio Catignani, Israeli Counterinsurgency and the Intifadas: Dilemmas of a Conventional Army (Oxford: Routledge, 2009).

${ }^{56}$ Levy, Israel's Materialist Militarism, 78-115, 147-179; Uri Ben-Eliezer, "Post-Modern Armies and the Question of Peace and War: The Israeli Defense Forces in The 'New Times," International Journal of Middle East Studies 36, no. 1 (2004); Stuart Cohen, "The Israel Defence Forces - From a 'People's Army' to a 'Professional Military' - Causes and Implications," Armed Forces and Society 21, no. 2 (1995).

${ }^{57}$ Yagil Levy, Edna Lomsky-Feder, and Noa Harel, "From 'Obligatory Militarism' to 'Contractual Militarism' Competing Models of Citizenship'," Israel Studies 12, no. 1 (2007): 127-48.

${ }^{58}$ Although the IDF does not publish official figures on the social background of its troops, it is possible to infer these trends from wider data. Levy, for example, has used casualty statistics. See Israel's Materialist Militarism, 117-125, 229-235; see also Gal Levy and Orna Sasson-Levy, "Militarized Socialisation, Military Service, and Class Reproduction: The Experiences of Israeli Soldiers," Sociological Perspectives 51, no. 2 (2008): 353-356; Orna Sasson-Levy, "Constructing Identities at the Margins: Masculinities and Citizenship in the Israeli Army," The Sociological Quarterly 43, no. 3 (2003): 362-363; Sasson-Levy, "Military, Masculinity, and Citizenship: Tensions and Contradictions in the Experience of Blue-Collar Soldiers," 233-235.

${ }^{59}$ Levy, Lomsky-Feder, and Harel, "From 'Obligatory Militarism' to ‘Contractual Militarism' - Competing Models of Citizenship'."

${ }^{60}$ B'Tselem, "B'Tselem's Camera Project," accessed August 12, 2016, http://www.btselem.org/video/cdp_background.

${ }^{61}$ Mati Milstein and Tom Mehager, "Black Labour: How a White Elite Uses Black Soldiers to Enforce Its Will," +972 Magazine, September 25, 2015, http://972mag.com/black-labor-how-a-white-elite-uses-blacksoldiers-to-enforce-its-will/112017/.

${ }^{62}$ Tom Mehager, Interview with the author, Jerusalem, July 8, 2016; Mati Milstein, Interview with the author, Skype, July 14, 2016.

${ }^{63}$ Milstein and Mehager, "Black Labour: How a White Elite Uses Black Soldiers to Enforce Its Will." 
${ }^{64}$ Itamar Taharlev, "David the Nahalawi, the periphery and the territories," HaOkets, May 28, 2014, http://www.haokets.org/2014/05/28/\%D7\%93\%D7\%95\%D7\%93-\%D7\%94\%D7\%A0\%D7\%97\%D7\%9C\%D7 \%90\%D7\%95\%D7\%95\%D7\%99-\%D7\%94\%D7\%A4\%D7\%A8\%D7\%99\%D7\%A4\%D7\%A8\%D7\%99\%D7\% 94-\%D7\%95\%D7\%94\%D7\%A9\%D7\%98\%D7\%97\%D7\%99\%D7\%9D/.

${ }^{65}$ Ibid.

${ }^{66}$ Haaretz, "This Purim, Some Israeli Kids Will Dress Up as Hebron Shooter," Haaretz, March 1, 2017, http://www.haaretz.com/israel-news/1.774212.

${ }^{67}$ Bhabha, The Location of Culture, 121-131.

${ }^{68}$ On "settler moves to innocence" see Eve Tuck and K. Wayne Yang, "Decolonization Is Not a Metaphor," Decolonization: Indigeneity, Education \& Society 1, no. 1 (September 8, 2012): 9-28, http://decolonization.org/index.php/des/article/download/18630.

${ }^{69}$ Mazor and Mehager, "What Would We Say about the Hebron Shooter Were He Ashkenazi?".

${ }^{70}$ Ibid

${ }^{71}$ Galit Distal Atbaryan, "Who is allowed to be shot: an immobilised terrorist or a youth who throws stones and runs away?," Ma'ariv Online, May 8, 2016,

http://www.nrg.co.il/online/1/ART2/776/029.html?hp=1\&cat=479\&loc=3.

${ }^{72}$ William Booth, "Israeli Colonel Who Killed a Palestinian Rock Thrower Was Following 'Protocol,"”

Washington Post, April 11, 2016, https://www.washingtonpost.com/news/worldviews/wp/2016/04/11/israelicolonel-who-killed-a-palestinian-rock-thrower-was-following-protocol/.

${ }^{73}$ James Eastwood, Ethics as Weapon of War: Militarism and Morality in Israel (Cambridge: Cambridge University Press, 2017).

${ }^{74}$ See, inter alia, Baruch Kimmerling, The Invention and Decline of Israeliness: State, Society, and the Military (Berkeley: University of California Press, 2005); Sara Helman, "Militarism and the Construction of

Community," Journal of Political and Military Sociology 25, no. 2 (1997); Sara Helman, "Militarism and the Construction of the Life-World of Israeli Males," in The Military and Militarism in Israeli Society, ed. Eyal Ben-Ari and Edna Lomsky-Feder (Albany: State University of New York Press, 1999); Eyal Ben-Ari, "Tests of Soldierhood, Trials of Manhood: Military Service and Male Ideals in Israel," in Military, State and Society in Israel: Theoretical and Comparative Perspectives, ed. David Maman, Eyal Ben-Ari, and Ze'ev Rosenhek (New Brunswick: Transaction Publishers, 2001); Orna Sasson-Levy, "Individual Bodies, Collective State Interests: The Case of Israel Combat Soldiers," Men and Masculinities 10, no. 3 (2008); Sasson-Levy, "Constructing Identities at the Margins: Masculinities and Citizenship in the Israeli Army."

${ }^{75}$ For scholarly discussions of this archetype, see Meira Weiss, The Chosen Body: The Politics of the Body in Israeli Society (Stanford: Stanford Univeristy Press, 2002); Oz Almog, Sabra: The Creation of the New Jew (Berkeley: University of California Press, 2000).

${ }^{76}$ Tamir Libel, "From the People's Army to the Jewish People's Army: The IDF's Force Structure between Professionalisation and Militarisation," Defence and Security Analysis 29, no. 4 (2013): 285-287.

${ }^{77}$ Makor Rishon Dyokan Magazine, "Building Jewish Identity: Prof. Benjamin Ish-Shalom and Former Chief of Staff Moshe Ya'alon Join Forces to Combat Israel's Identity Crisis," October 13, 2006,

http://www.bmj.org.il/userfiles/articles/Building\%20Jewish\%20Identity\%20-\%20Yaalon\%20\&\%20IshShalom.pdf.

${ }_{78}^{78}$ Michal Feuras, Interview with the author, Tel Aviv, April 9, 2013.

${ }^{79}$ Eastwood, “'Meaningful Service': Pedagogy at Israeli Pre-Military Academies and the Ethics of Militarism," 679.

${ }^{80}$ Yael Domb, Interview with the author, Jerusalem, November 21, 2012.

${ }^{81}$ Patrick Wolfe, "Settler Colonialism and the Elimination of the Native," Journal of Genocide Research 8, no. 4 (2006): 387-409.

${ }^{82}$ Butler, "Endangered/endangering: Schematic Racism and White Paranoia," 15.

${ }^{83}$ Ibid., 18.

${ }^{84}$ Ibid.

${ }^{85}$ Ibid., 20. 